\title{
Optimizing Tillage and Irrigation Requirements of Sorghum in Sorghum-Pigeonpea Intercrop in Hamelmalo Region of Eritrea
}

\author{
Tesfalem Weldeslassie, Ramesh Prasad Tripathi*, Woldeselassie Ogbazghi \\ Department of Land Resources and Environment, Hamelmalo Agricultural College, Keren, Eritrea \\ Email: tesfaweld333@gmail.com, "rp.tripathi52@gmail.com,wogbazghi@gmail.com
}

Received 23 February 2016; accepted 23 April 2016; published 26 April 2016

Copyright $@ 2016$ by authors and Scientific Research Publishing Inc.

This work is licensed under the Creative Commons Attribution International License (CC BY). http://creativecommons.org/licenses/by/4.0/

(c) (i) Open Access

\section{Abstract}

Sorghum (Sorghum bicolor L. Moench) is cultivated as monocrop in Eritrea. Efforts were made to grow sorghum-pigeonpea (Cajanus cajan L. Millspp.) intercrop on the tillage, fertilizers and supplementary irrigations necessary for sorghum. Experiments were conducted in terraced fields at Hamelmalo during 2013-15 to evaluate growth and yield of sorghum-pigeonpea intercrop in split plot design with conventional tillage (CT), reduced tillage (RT) and zero tillage (ZT) in main plots and rainfed $\left(I_{0}\right), 50 \%$ of full irrigation $\left(I_{1}\right), 75 \%$ of full irrigation $\left(I_{2}\right)$ and $100 \%$ of full irrigation $\left(I_{3}\right)$ in subplots. All irrigations were stopped 15 days before sorghum maturity. Full irrigation was 60 $\mathrm{mm}$ applied at $50 \%$ depletion of available soil water in $1 \mathrm{~m}$ profile. Sorghum growth was faster than pigeonpea until 85 days from planting and pigeonpea growth accelerated only after sorghum harvesting. About $80 \%$ of sorghum roots were within $0.6 \mathrm{~m}$ profile but more than $75 \%$ of pigeonpea roots were below $0.60 \mathrm{~m}$ depth. This showed a weaker competition between the two crops for nutrients, water and light. Both grain and stover yields of sorghum were optimum in $R T+I_{2}$ during the 2 years. Highest grain yield was $6900 \mathrm{~kg} \cdot \mathrm{ha}^{-1}$ in $\mathrm{RT}+\mathrm{I}_{3}$ in 2013 , which was at par with that in $R T+I_{2}$. Mean residual soil moisture at sorghum harvesting was $74 \mathrm{~mm} \cdot \mathrm{m}^{-1}$, which decreased to $8 \mathrm{~mm} \cdot \mathrm{m}^{-1}$ by pigeonpea harvesting. Residual moisture was more in the irrigated than non-irrigated plots. Pigeonpea yields were optimum $\left(1363 \mathrm{~kg} \cdot \mathrm{ha}^{-1}\right)$ in $R T+I_{3}$ and lowest $\left(297 \mathrm{~kg} \cdot \mathrm{ha}^{-1}\right)$ in ZT $+I_{0}$. Average water use by sorghum-pigeonpea was $374 \mathrm{~mm}$ by sorghum harvesting and 438 mm by pigeonpea harvesting, producing total sorghum equivalent yield of $7475 \mathrm{~kg} \cdot \mathrm{ha}^{-1}$. This raised average water use efficiency from $12.6 \mathrm{~kg} \cdot \mathrm{ha}^{-1} \cdot \mathrm{mm}^{-1}$ at sorghum harvesting to 17.1 $\mathrm{kg} \cdot \mathrm{ha}^{-1} \cdot \mathrm{mm}^{-1}$ at pigeonpea harvesting. Benefit was doubled at $50 \%$ of full irrigation and $>4$ times at $75 \%$ of full irrigation.

\footnotetext{
${ }^{*}$ Corresponding author.
} 


\section{Keywords}

\section{Residual Soil Moisture, Sorghum-Pigeonpea Intercrop, Supplementary Irrigation, Water Use Efficiency}

\section{Introduction}

Sorghum (Sorghum bicolor L. Moench) is a major crop of Eritrea contributing about 46\% of the total cereal production [1]. However, its productivity has been below $0.6 \mathrm{t}^{\mathrm{h}} \mathrm{ha}^{-1}$ due to improper rainwater management, lack of available soil moisture at grain filling stages, low inputs and poor soil and crop management [2] [3]. Sorghum yields could be optimized through adoption of rainwater management and conservation tillage practices [3]-[6] and minimizing risks due to agricultural droughts through supplemental irrigations [7]-[10]. Water stress at vegetative stage alone reduced sorghum yields more than $36 \%$ and that during boot to reproductive stages more than 55\% [11]. Sivakumar et al. [12] observed that two irrigations increased sorghum yields from 2430 - 5990 $\mathrm{kg} \cdot \mathrm{ha}^{-1}$. Single $50 \mathrm{~mm}$ irrigation from runoff harvesting in the watershed increased sorghum yields from 2570$3570 \mathrm{~kg} \cdot \mathrm{ha}^{-1}$ [13] [14].

Among the crop production factors, tillage contributed about 20\% to the economic yield [15] through optimization of conditions for germination, seedling establishment and crop growth [14] [16]. Reduced or zero tillage also provided most of these services [17] together with increased carbon and nitrogen storage and soil aggregate stability [3] [18]-[20]. West et al. [21] observed 50\% - 67\% higher water-stable aggregates in soil under zero than conventional tillage. Bear et al. [22] observed that micro-aggregates $(<2.5 \mathrm{~mm})$ in soil under zero tillage were $21 \%$ - $65 \%$ higher than under conventional tillage. Mean weight diameter of aggregates increased by $16 \%$ in 5 years of zero tillage [23]. A positive correlation was observed between aggregate stability and total soil organic carbon [23]-[26]. Both dry-and water-stable aggregates in soil were better under zero tillage than conventional tillage [27]-[29]. Most farmers in Hamelmalo region till thrice before sorghum planting, which needs to be optimized for reducing not only the cost of cultivation but also land degradation. Canadian studies have shown significantly higher yields $\left(2.8 \mathrm{t} \cdot \mathrm{ha}^{-1}\right)$ without nitrogen applications after 20 years of zero tillage with full stubble retention [30]. Protein content of grains was much higher under zero than conventional tillage.

Rainfed sorghum is open to serious risks due to water stress during critical growth stages and agricultural droughts. Assured sorghum yields of about $4 \mathrm{t} \cdot \mathrm{ha}^{-1}$ were possible by irrigating once in the terraced plots leaving significant amount of residual soil moisture [4] [6]. Intercropping of pigeonpea would be step towards achieving food security and soil quality improvements. Soils of Anseba region are deep alluvium, medium to coarser in texture but rainwater rapidly runs off due to highly sloping traditional cultivated fields and that infiltrating percolates beyond the crop root zone in the terraced fields [3] [4] accelerating agricultural droughts. About 80 - 150 $\mathrm{mm}$ residual moisture per $2 \mathrm{~m}$ of soil profile was observed at sorghum harvesting in the well managed watersheds ensuing zero runoff [4]-[6]. Considerable residual soil moisture at sorghum harvesting in managed watersheds provided opportunity for growing a legume intercrop like pigeonpea of shorter duration with sorghum that could survive on the residual moisture [4]. Pigeonpea grows slowly during the early vegetative phase and because of its longer duration and deep rooting character to exploit residual moisture, it is eminently suitable as intercrop that does not adversely affect the yield of sorghum [31]-[35]. Gwata and Shimelis [36] reported that Eastern Africa is secondary centre of diversity for pigeonpea. Crop duration ranged from 130 days (short) to 150 days (medium), or 180 days (long). It can produce 2.5 - 5 t dry peas ha ${ }^{-1}$ and provide 4 - $8 \mathrm{t} \cdot \mathrm{ha}^{-1}$ of stalk for thatch building material, fuel wood and fodder [37] [38]. Pigeonpea adds substantial amount of organic matter in soil and can fix up to $235 \mathrm{~kg} \mathrm{~N} \mathrm{ha}^{-1}$ [38] [39]. Pigeonpea produces more $\mathrm{N}$ per unit area from plant biomass than many legumes. Pigeonpea intercropped with sorghum fixed 35.94 - $164.82 \mathrm{~kg} \mathrm{~N} \mathrm{ha}^{-1}$ [40]. Pod borer infestation is a major problem in pigeonpea, which is greatly controlled by harbouring and nourishing of its predator Trichogramma spp. in sorghum-pigeonpea intercrop [41]. Intercropping with sorghum reduced wilt incidence in pigeonpea [20]. Vijayalskshmi et al. [42] reported that supplemental irrigations increased sorghum-pigeonpea yields by $560 \%$. Supplementary irrigations not only improved sorghum yields but also facilitated stored rainwater use efficiency and residual soil moisture use by pigeonpea [5]. Objective of this research was thus to optimize tillage and supplementary irrigations for sorghum in sorghum-pigeonpea intercrop and demonstrate the pos- 
sibility of raising pigeonpea on the inputs applied for sorghum.

\section{Materials and Methods}

\subsection{Soil}

The experimental soil was sandy loam comprising of $60 \%$ sand, $29.5 \%$ silt and $10.5 \%$ clay in block C of the model watershed at Hamelmalo Agricultural College $\left(15^{\circ} 52^{\prime} 20.6^{\prime \prime} \mathrm{N}\right.$ and $38^{\circ} 27^{\prime} 57.6^{\prime \prime} \mathrm{E}$ at $1280 \mathrm{msl}$ ), in the semiarid region of Eritrea. Annual rainfall in the past seven years ranged from 370 - $663.1 \mathrm{~mm}$ with a mean of 488 $\mathrm{mm}$ and average annual pan evaporation of $1931 \mathrm{~mm}$. Highest mean monthly temperature occurred in May $\left(35.7^{\circ} \mathrm{C}\right)$ and lowest in January $\left(11.1^{\circ} \mathrm{C}\right)$. Total rainfall was $388 \mathrm{~mm}$ in 2013 and $429 \mathrm{~mm}$ in 2014 (Figure 1).

The soil was non-saline (EC $0.18 \mathrm{dS} \cdot \mathrm{m}^{-1}$ ) with $\mathrm{pH}$ of 8.2 and average bulk density of $1.5 \mathrm{Mg} \cdot \mathrm{m}^{-3}$ (Table 1). Field capacity and wilting points of soil were 0.175 and $0.053 \mathrm{~m}^{3} \cdot \mathrm{m}^{-3}$, respectively. The organic matter content was $0.27 \%$ and available $\mathrm{N}$ was $0.05 \%$. The available $\mathrm{P}$ and $\mathrm{K}$ were $0.88 \mathrm{mg} \cdot \mathrm{kg}^{-1} 0.25 \mathrm{cmol} \cdot \mathrm{kg}^{-1}$, respectively.

\subsection{Treatments}

The experiment was conducted in split plot design with three tillage treatments viz., conventional tillage (CT), reduced tillage (RT) and zero tillage (ZT) in main plots and four irrigation treatments viz., rainfed $\left(\mathrm{I}_{0}\right), 50 \%$ of full irrigation $\left(\mathrm{I}_{1}\right), 75 \%$ of full irrigation $\left(\mathrm{I}_{2}\right)$ and full irrigation $\left(\mathrm{I}_{3}\right)$ in subplots in three replications. CT refers to three passes of traditional bullock-drawn plough followed by row planting and RT refers to one pass of bullock-drawn plough 4 days after heavy rainfall followed by row planting. Zero tillage (ZT) was direct planting in rows. Full irrigation was $50 \%$ depletion of available soil water in $1 \mathrm{~m}$ profile. All irrigations were stopped 15 days before sorghum maturity. Each subplot was $4.0 \mathrm{~m} \times 4.5 \mathrm{~m}$, separated by $2 \mathrm{~m}$ passage. Bunds of width 0.4 $\mathrm{m}$ and height $0.3 \mathrm{~m}$ were formed around each plot to avoid any runoff or run-on.

Sorghum variety ICSV 210 (BUSHUKA) and pigeonpea variety ICEAP 00040 were planted at a seed rate of 12 and $10 \mathrm{~kg} \cdot \mathrm{ha}^{-1}$, respectively, on July 7 in 2013 and July 14 in 2014 in alternate rows, $0.375 \mathrm{~m}$ apart. The

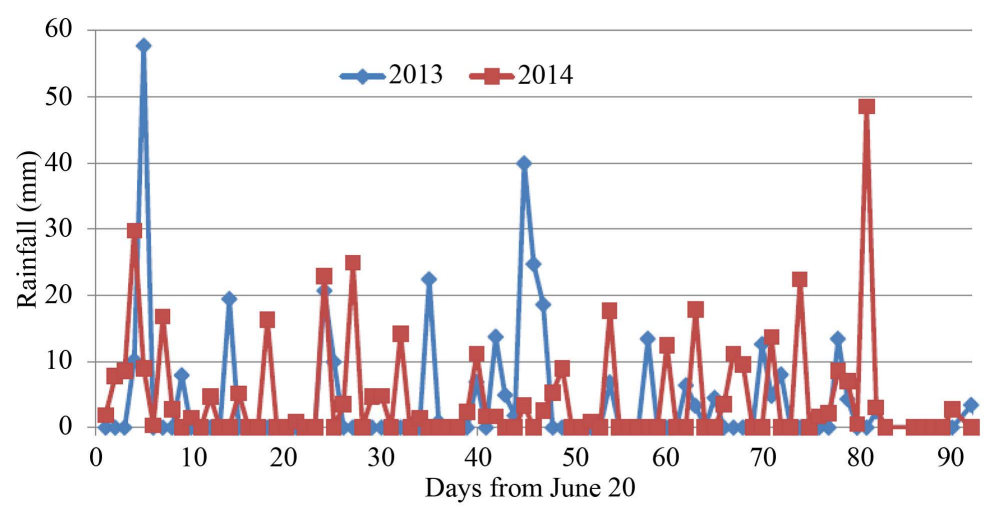

Figure 1. Rainfall during the crop season of 2013 and 2014 at Hamelmalo.

Table 1. Properties of the experimental soil.

\begin{tabular}{|c|c|c|c|c|c|c|c|c|c|c|c|c|c|}
\hline \multirow{2}{*}{$\begin{array}{l}\text { Depth, } \\
\text { m }\end{array}$} & \multicolumn{3}{|c|}{ Soil Fractions, \% } & \multirow{2}{*}{ Texture } & \multirow{2}{*}{$\begin{array}{c}\mathrm{pH} \\
(1: 5)\end{array}$} & \multirow{2}{*}{$\begin{array}{c}\mathrm{EC} \\
\mathrm{dS} \cdot \mathrm{m}^{-1}\end{array}$} & \multirow{2}{*}{$\begin{array}{c}\text { OM, } \\
\%\end{array}$} & \multirow{2}{*}{$\mathrm{N}, \%$} & \multirow{2}{*}{$\begin{array}{l}\mathrm{P}, \mathrm{mg} \\
\mathrm{kg}^{-1}\end{array}$} & \multicolumn{4}{|c|}{ Exchangeable Cations, cmolc kg ${ }^{-1}$} \\
\hline & Sand & Silt & Clay & & & & & & & $\mathrm{Ca}^{++}$ & $\mathrm{Mg}^{++}$ & $\mathrm{K}^{+}$ & $\mathrm{Na}^{+}$ \\
\hline $0-0.2$ & 83 & 11 & 6 & $\begin{array}{c}\text { Loamy } \\
\text { sand }\end{array}$ & 7.8 & 0.08 & 0.65 & 0.06 & 9.32 & 11.5 & 3 & 0.15 & 0.35 \\
\hline $0.2-0.5$ & 70 & 14 & 16 & $\begin{array}{l}\text { Sandy } \\
\text { loam }\end{array}$ & 8.2 & 0.08 & 0.42 & 0.05 & 3.71 & 15.0 & 5 & 0.10 & 0.47 \\
\hline $0.5-0.3$ & 61 & 20 & 19 & $\begin{array}{l}\text { Sandy } \\
\text { loam }\end{array}$ & 8.2 & 0.14 & 0.42 & 0.05 & 2.91 & 20.0 & 5 & 0.14 & 0.55 \\
\hline$>1.3$ & 89 & 7 & 4 & Sand & 8.4 & 0.15 & 0.32 & 0.04 & 3.61 & 29.0 & 8 & 0.11 & 0.51 \\
\hline
\end{tabular}


sorghum was planted at a distance of $0.2 \mathrm{~m}$ and pigeonpea at $0.4 \mathrm{~m}$ within rows. Fertilizers applied were DAP at $100 \mathrm{~kg} \cdot \mathrm{ha}^{-1}$ before sowing and urea at $50 \mathrm{~kg} \cdot \mathrm{ha}^{-1}$ at 25 and 45 days from planting recommended for sorghum by National Agricultural Research Institute, Halhale, Eritrea. Hand weeding was done before topdressing urea. Soil moisture was determined gravimetrically by sampling $0.05 \mathrm{~m}$ length and diameter soil core from the midpoint of $0.25 \mathrm{~m}$ depth increment down to $1 \mathrm{~m}$ at sowing and 20 days interval until first week of September and at 10 days interval thereafter to determine irrigation date. Irrigation day was at $50 \%$ depletion of available soil moisture in $1 \mathrm{~m}$ profile. Net irrigation was $60 \mathrm{~mm}$ in $\mathrm{I}_{3}$ (full irrigation), $45 \mathrm{~mm}$ in $\mathrm{I}_{2}$ ( $75 \%$ of full irrigation) and $30 \mathrm{~mm}$ in $\mathrm{I}_{1}$ (50\% of full irrigation) applied on September 11 and 21 and October 2 in 2013 and September 24 and October 4 in 2014. Hand weeding was done twice and CARBARAYL insecticide was applied two times @ $2 \mathrm{~g}$ per litre of water to control pod borer. Grain and stover yields were determined by harvesting central $3 \mathrm{~m} \times 3 \mathrm{~m}$ area and threshing manually. Pigeonpea was harvested when over $80 \%$ of the pods become brown. The grain was dried to $14 \%$ moisture.

\subsection{Water Use}

Crop water use (ET, $\mathrm{mm})$ was determined using water balance equation as

$$
\mathrm{ET}=\mathrm{RF}+\mathrm{SI} \pm \Delta \mathrm{S}-\mathrm{DP}-\mathrm{RO}
$$

where $\mathrm{RF}$ is rainfall, $\mathrm{mm}$, $\mathrm{SI}$ is supplemental irrigation, $\mathrm{mm}, \Delta \mathrm{S}$ is change in soil moisture storage, $\mathrm{mm}$, $\mathrm{DP}$ is deep percolation, $\mathrm{mm}$, and RO is runoff, $\mathrm{mm}$. Both DP and RO were zero because all plots were well bunded and storm rainfall never exceeded available water storage capacity of the root zone.

\subsection{Root Length Density}

Root length density (RLD) was determined at harvesting of the two crops by line intersection method of Tennant [43]. Root samples were drawn from each treatment in $0.15 \mathrm{~m}$ soil depth increments down to $1.2 \mathrm{~m}$ by placing $0.1 \mathrm{~m}$ diameter root sampler on the harvested hill. Root samples were collected in plastic bags for saturation overnight followed by washing in soil-root wash basin. Soil-root mixture in the wash basin was stirred to disperse roots and water was supplied continuously to allow suspended roots to pass through the drain pipe into the sieves arranged in the order of 2, 0.650 , and $0.355 \mathrm{~mm}$. Roots were randomly spread by tweezers in a dish containg a film of water and number of roots with vertical and horizontal grid lines of $10 \mathrm{~mm}$ were counted and $\operatorname{RLD}\left(\mathrm{cm}^{\mathrm{cm}}{ }^{-3}\right)$ was calculated as

$$
\operatorname{RLD}=\frac{R}{V}
$$

where $R$ is root length, cm, expressed as

$$
R=\frac{11}{14} N \text { Grid units }
$$

where $N$ is number of intersections and $V$ is soil core volume, $\mathrm{cm}^{3}$. Percent root distribution was calculated as

$$
\% \text { Root distribution }=\frac{\text { RLD in ith layer }}{\text { Total RLD }}
$$

\subsection{Sorghum Equivalent Grain Yield}

The sorghum equivalent grain yield (SEY) was calculated to express total yield in terms of sorghum for sorghum-pigeonpea intercrop. The SEY was based on per kg market price of the two crops using the relation:

$$
\mathrm{SEY}=\mathrm{Ys}+(\mathrm{MRp} / \mathrm{MRs}) \times \mathrm{Yp}
$$

where Ys is sorghum yield $\left(\mathrm{kg}^{-1} \mathrm{ha}^{-1}\right)$, MRp is market rate of pigeonpea (Eritrean NKF kg${ }^{-1}$ ), MRs is market rate of sorghum (Eritrean NKF kg ${ }^{-1}$ ), and Yp is pigeonpea yield $\left(\mathrm{kg} \cdot \mathrm{ha}^{-1}\right.$ ). Prevailing market price of the crops $\mathrm{kg}^{-1}$ was collected from the open market in ERN (Eritrean Nakfa). Pigeonpea is not common in Eritrea but it is one of the costliest pulses in the international market and, therefore, Its market price was considered twice that of the sorghum. 


\section{Results and Discussion}

\subsection{Growth Pattern of Sorghum and Pigeonpea}

Sorghum vegetative growth was relatively better in CT and RT plots than in ZT, perhaps because ZT was more affected by weeds in the initial establishment period. Irrigations were applied from reproductive phase. Sorghum growth was faster than pigeonpea during the initial 85 days from sowing although both were planted on the same date (Figure 2). Pigeonpea grew faster only after sorghum harvesting in 115 - 120 days and thus did not compete with sorghum crop in the initial stages. At sorghum harvesting, only $3 \%$ of pigeonpea plants were approaching flowering. Pigeonpea is known to lack synchronous flowering and maturity. However, variety planted in the experiment appears to be wilder type because flowering and maturity continued for several months after sorghum harvesting. Pigeonpea plants survived green even beyond March but net plot was harvested by end of January. Shorter duration improved pigeonpea varieties are now available and would be better option.

\subsection{Rooting Pattern of Sorghum and Pigeonpea}

About 80\% sorghum roots in sorghum-pigeonpea intercrop were within $0.6 \mathrm{~m}$ soil profile, of which more than $60 \%$ were in the top $0-0.20 \mathrm{~m}$ layer (Figure 3). On the contrary, more than $75 \%$ pigeonpea roots were below $0.60 \mathrm{~m}$ depth in the soil. Rooting patterns of sorghum-pigeonpea intercrop thus have a weak competition between them for water and nutrient extraction zone in the soil profile.

\subsection{Grain yield of Sorghum}

Mean sorghum yields due to tillage were not significant in both the years (Table 2). But mean yields due to supplementary irrigations were significantly greater in $I_{2}$ than in $I_{1}$ both in 2013 and 2014. Yields were at par in
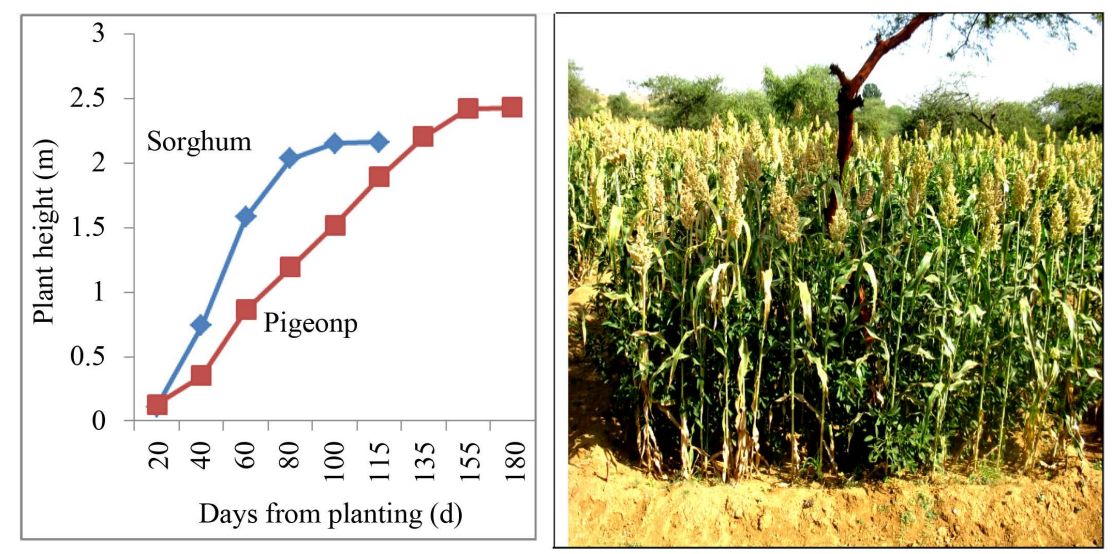

Figure 2. Average growth pattern of sorghum and pigeonpea.

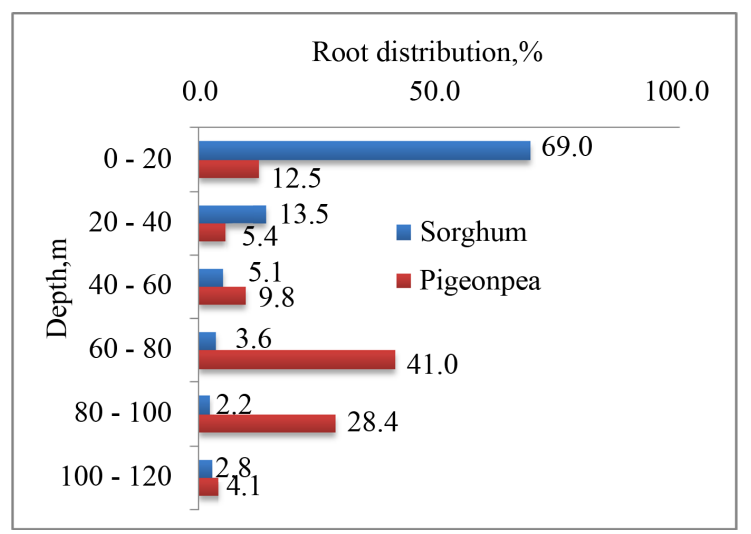

Figure 3. Average root distribution patterns of sorghum and pigeonpea. 
$I_{2}$ and $I_{3}$. Interaction of tillage and irrigations showed that grain yields in $R T+I_{2}$ and $R T+I_{3}$ were at par in both the years and significantly greater than in $\mathrm{RT}+\mathrm{I}_{1}$. However, despite more and better distributed rainfall in 2014 yields were lower than in 2013 except in $\mathrm{I}_{0}$. Decreasing trends in yield indicate growing deficiency of nutrients other than applied $\mathrm{N}$ and $\mathrm{P}$. Potassium deficiency symptoms were common.

\subsection{Stover Yield of Sorghum}

Mean stover yields were independent of tillage but were significantly higher in $\mathrm{I}_{2}$ and $\mathrm{I}_{3}$ than in $\mathrm{I}_{1}$ (Table 3). Interaction effects showed significantly higher yields in $\mathrm{RT}+\mathrm{I}_{3}$ in 2013 and in $\mathrm{RT}+\mathrm{I}_{2}$ in 2014. Halving et al. [20] also observed greater stover production in sorghum due to improved nutrient uptake.

\subsection{Grain and Stalk Yields of Pigeonpea}

Two-year average grain and stalk yields of pigeonpea are shown in Table 4. Mean grain yields of pigeonpea due to tillage were significantly higher in CT $\left(1098 \mathrm{~kg} \cdot \mathrm{ha}^{-1}\right)$ and that due to irrigations were higher in $\mathrm{I}_{3}(1271$ $\mathrm{kg} \cdot \mathrm{ha}^{-1}$ ). Increases in yields were $215 \%$ in $\mathrm{I}_{1}$ from $\mathrm{I}_{0}$ and $153 \%$ in $\mathrm{I}_{2}$ from $\mathrm{I}_{1}$. Interaction effects showed that pigeonpea yields increased significantly with irrigations for sorghum in ZT and RT. Yields were at par in CT + $\mathrm{I}_{2}$ and $\mathrm{RT}+\mathrm{I}_{3}$. Since all inputs such as tillage, fertilizers and irrigations were applied based on requirements for sorghum, possibility of raising pigeonpea on residual soil moisture in sorghum-pigeonpea intercrop are promising.

Table 2. Grain yield of sorghum under different tillage and irrigations.

\begin{tabular}{|c|c|c|c|c|c|c|c|c|c|c|}
\hline \multirow{2}{*}{ Tillage } & \multicolumn{5}{|c|}{ Grain Yield $\left(\mathrm{kg} \cdot \mathrm{ha}^{-1}\right)$ in 2013 under } & \multicolumn{5}{|c|}{ Grain Yield $\left(\mathrm{kg} \cdot \mathrm{ha}^{-1}\right)$ in 2014 under } \\
\hline & $\mathrm{I}_{0}$ & $\mathrm{I}_{1}$ & $\mathrm{I}_{2}$ & $\mathrm{I}_{3}$ & Mean & $\mathrm{I}_{0}$ & $\mathrm{I}_{1}$ & $\mathrm{I}_{2}$ & $\mathrm{I}_{3}$ & Mean \\
\hline $\mathrm{ZT}$ & 1700 & 4300 & 5700 & 5400 & 4200 & 2833 & 4222 & 5389 & 4667 & 4278 \\
\hline $\mathrm{RT}$ & 2600 & 4700 & 6200 & 6900 & 5100 & 3556 & 4222 & 5444 & 5389 & 4653 \\
\hline $\mathrm{CT}$ & 2600 & 5000 & 6600 & 6600 & 5200 & 3333 & 3778 & 4889 & 4944 & 4236 \\
\hline Mean & 2300 & 4600 & 6100 & 6200 & & 3241 & 4074 & 5241 & 5000 & \\
\hline Factors & $\mathrm{T}$ & I & $\mathrm{T} \times \mathrm{I}$ & & & $\mathrm{T}$ & I & $\mathrm{T} \times \mathrm{I}$ & & \\
\hline LSD, 5\% & NS & 467 & 989 & & & NS & 458 & 1217 & & \\
\hline
\end{tabular}

Table 3. Stover yield of sorghum under different tillage and irrigation levels.

\begin{tabular}{|c|c|c|c|c|c|c|c|c|c|c|}
\hline \multirow{2}{*}{ Tillage } & \multicolumn{5}{|c|}{ Stover Yield $\left(\mathrm{kg} \cdot \mathrm{ha}^{-1}\right)$ in 2013 under } & \multicolumn{5}{|c|}{ Stover Yield $\left(\mathrm{kg} \cdot \mathrm{ha}^{-1}\right)$ in 2014 under } \\
\hline & $\mathrm{I}_{0}$ & $\mathrm{I}_{1}$ & $\mathrm{I}_{2}$ & $\mathrm{I}_{3}$ & Mean & $\mathrm{I}_{0}$ & $\mathrm{I}_{1}$ & $\mathrm{I}_{2}$ & $\mathrm{I}_{3}$ & Mean \\
\hline ZT & 1811 & 4744 & 8222 & 8033 & 5700 & 4000 & 4889 & 6111 & 8111 & 5778 \\
\hline RT & 2633 & 5444 & 9522 & 11033 & 7156 & 4222 & 6611 & 9611 & 9056 & 7375 \\
\hline CT & 2667 & 5811 & 7811 & 9189 & 6367 & 4944 & 5889 & 8222 & 6833 & 6472 \\
\hline Mean & 2367 & 5333 & 8522 & 9422 & & 4389 & 5796 & 7981 & 8000 & \\
\hline Factors & $\mathrm{T}$ & I & $\mathrm{T} \times \mathrm{I}$ & & & $\mathrm{T}$ & I & $\mathrm{T} \times \mathrm{I}$ & & \\
\hline LSD, 5\% & NS & 1078 & 2866 & & & 1994 & 9552 & 2153 & & \\
\hline
\end{tabular}

Table 4. Two-year average grain and stalk yields of pigeonpea under different tillage and irrigations to sorghum.

\begin{tabular}{|c|c|c|c|c|c|c|c|c|c|c|}
\hline \multirow{2}{*}{ Tillage } & \multicolumn{5}{|c|}{ Grain Yield $\left(\mathrm{kg} \cdot \mathrm{ha}^{-1}\right)$ under Iirrigations } & \multicolumn{5}{|c|}{ Stalk Yield $\left(\mathrm{kg} \cdot \mathrm{ha}^{-1}\right)$ under Irrigations } \\
\hline & $\mathrm{I}_{0}$ & $\mathrm{I}_{1}$ & $\mathrm{I}_{2}$ & $\mathrm{I}_{3}$ & Mean & $\mathrm{I}_{0}$ & $\mathrm{I}_{1}$ & $\mathrm{I}_{2}$ & $\mathrm{I}_{3}$ & Mean \\
\hline $\mathrm{ZT}$ & 297 & 556 & 881 & 1046 & 694 & 2011 & 3556 & 4000 & 4444 & 3511 \\
\hline RT & 322 & 500 & 1074 & 1363 & 814 & 2122 & 2911 & 4378 & 5222 & 3644 \\
\hline CT & 409 & 1156 & 1422 & 1406 & 1098 & 2000 & 5556 & 5778 & 5333 & 4700 \\
\hline Mean & 342 & 737 & 1126 & 1271 & & 2044 & 4022 & 4722 & 5000 & \\
\hline Factors & $\mathrm{T}$ & I & $\mathrm{T} \times \mathrm{I}$ & & & $\mathrm{T}$ & I & $\mathrm{T} \times \mathrm{I}$ & & \\
\hline LSD, 5\% & 117 & 97 & 167 & & & 389 & 511 & 822 & & \\
\hline
\end{tabular}


Mean stalk yields of pigeonpea due to tillage were significantly higher under CT than ZT and RT (Table 4) and that due to irrigations were significantly higher under $I_{2}$. Interaction effects showed significantly higher stalk yield in $\mathrm{RT}+\mathrm{I}_{3}$. Since sorghum is main crop and water is a most limiting factor of crop production in Eritrea, $\mathrm{RT}+\mathrm{I}_{2}$ would be better choice.

\subsection{Sorghum Equivalent Grain Yield}

Mean sorghum equivalent grain yields due to tillage were at par in RT and CT but significantly greater than in ZT (Table 5). However, mean sorghum equivalent yields (SEY) due to irrigations increased significantly from $\mathrm{I}_{0}$ to $\mathrm{I}_{3}$. Interaction effects showed that yields were at par in $\mathrm{RT}+\mathrm{I}_{3}, \mathrm{CT}+\mathrm{I}_{2}$ and $\mathrm{CT}+\mathrm{I}_{3}$. Since sorghum was the main crop for which RT was most optimum, the choice would go for $\mathrm{RT}+\mathrm{I}_{2}$, which was the next best tillage + irrigation combination. Choice for $\mathrm{I}_{3}$ should depend on availability of irrigation resources with the farmer.

\subsection{Residual Soil Moisture}

Mean residual soil moisture at sorghum harvesting increased from $60 \mathrm{~mm} \cdot \mathrm{m}^{-1}$ under rainfed to $80 \mathrm{~mm} \cdot \mathrm{m}^{-1}$ under $75 \%$ of full irrigation (Table 6). Results thus show that supplementary irrigations to optimize sorghum yields leave considerable quantity of residual moisture, which can be used by the pigeonpea crop. About $85 \%$ $90 \%$ of residual moisture was consumed by pigeonpea.

\subsection{Water Use by Sorghum + Pigeonpea and Water Productivity}

Water use by sorghum-pigeonpea intercrop was almost independent of tillage but increased with irrigations (Table 7). Highest water use was recorded in $\mathrm{RT}+\mathrm{I}_{3}(522 \mathrm{~mm})$ and lowest in $\mathrm{ZT}+\mathrm{I}_{0}(276 \mathrm{~mm})$. Average water use by sorghum-pigeonpea was lowest $(366 \mathrm{~mm})$ under RT and highest $(440 \mathrm{~mm})$ under CT.

Production function showed that sorghum equivalent yield increased with water use rapidly to $9363 \mathrm{~kg} \cdot \mathrm{ha}{ }^{-1}$ for which water use was $478 \mathrm{~mm}$ (Figure 4). At harvesting of pigeonpea mean water use increased to $438 \mathrm{~mm}$ from $374 \mathrm{~mm}$ at sorghum harvesting. As shown in Figure 5, sorghum yield of $6600 \mathrm{~kg} \cdot \mathrm{ha}^{-1}$ and pigeonpea yield of $1422 \mathrm{~kg} \cdot \mathrm{ha}^{-1}$ could be obtained by water use of $478 \mathrm{~mm}$. The water use efficiency was maximum (19.6 $\left.\mathrm{kg} \cdot \mathrm{ha}^{-1} \cdot \mathrm{mm}^{-1}\right)$ in $\mathrm{CT}+\mathrm{I}_{2}$ and minimum $\left(6.8 \mathrm{~kg} \cdot \mathrm{ha}^{-1} \cdot \mathrm{mm}^{-1}\right)$ in $\mathrm{ZT}+\mathrm{I}_{0}$.

Table 5. Sorghum equivalent grain yield under different tillage and supplementary irrigations.

\begin{tabular}{|c|c|c|c|c|c|}
\hline \multirow{2}{*}{$\begin{array}{c}\text { Tillage } \\
\text { Treatments }\end{array}$} & \multicolumn{4}{|c|}{ Sorghum Equivalent Yield $\left(\mathrm{kg} \cdot \mathrm{ha}^{-1}\right)$ under Irrigations } & \multirow{2}{*}{ Mean } \\
\hline & $\mathrm{I}_{0}$ & $\mathrm{I}_{1}$ & $\mathrm{I}_{2}$ & $\mathrm{I}_{3}$ & \\
\hline $\mathrm{ZT}$ & 2315 & 5445 & 7430 & 7536 & 5681 \\
\hline RT & 3237 & 5815 & 8315 & 9633 & 6750 \\
\hline CT & 3374 & 7348 & 9363 & 9441 & 7382 \\
\hline Mean & 2975 & 6203 & 8369 & 8870 & \\
\hline Factors & $\mathrm{T}$ & I & $\mathrm{T} \times \mathrm{I}$ & & \\
\hline $\operatorname{LSD}(p=0.05)$ & 914 & 472 & 1014 & & \\
\hline
\end{tabular}

Table 6. Residual soil moisture $\left(\mathrm{mm} \cdot \mathrm{m}^{-1}\right)$.

\begin{tabular}{|c|c|c|c|c|c|c|c|c|}
\hline \multirow{3}{*}{ Tillage Treatments } & \multicolumn{8}{|c|}{ Residual Moisture (mm) at Harvesting of Sorghum $\left(1^{*}\right)$ and Pigeonpea $\left(2^{*}\right)$ under } \\
\hline & \multicolumn{2}{|c|}{$\mathrm{I}_{0}$} & \multicolumn{2}{|c|}{$\mathrm{I}_{1}$} & \multicolumn{2}{|c|}{$\mathrm{I}_{2}$} & \multicolumn{2}{|c|}{$\mathrm{I}_{3}$} \\
\hline & $1^{*}$ & $2^{*}$ & $1^{*}$ & $2^{*}$ & $1^{*}$ & $2^{*}$ & $1^{*}$ & $2^{*}$ \\
\hline $\mathrm{ZT}$ & 6.47 & 0.00 & 7.7 & 0.00 & 7.8 & 0.00 & 7.70 & 2.30 \\
\hline RT & 5.70 & 0.90 & 6.90 & 0.80 & 8.00 & 1.63 & 7.10 & 0.93 \\
\hline $\mathrm{CT}$ & 5.90 & 0.00 & 7.30 & 0.00 & 8.10 & 0.50 & 8.30 & 2.80 \\
\hline Mean & 6.00 & 0.30 & 7.30 & 0.27 & 8.00 & 0.70 & 7.70 & 2.00 \\
\hline
\end{tabular}


Table 7. Water use by sorghum + pigeonpea under different tillage and irrigations.

\begin{tabular}{|c|c|c|c|c|c|c|c|c|c|c|}
\hline \multirow{3}{*}{$\begin{array}{l}\text { Tillage } \\
\text { Treatments }\end{array}$} & \multicolumn{8}{|c|}{ Water Use $(\mathrm{mm})$ by Sorghum + Pigeonpea under Irrigations } & \multirow{2}{*}{\multicolumn{2}{|c|}{ Mean }} \\
\hline & \multicolumn{2}{|c|}{$\mathrm{I}_{0}$} & \multicolumn{2}{|c|}{$\mathrm{I}_{1}$} & \multicolumn{2}{|c|}{$\mathrm{I}_{2}$} & \multicolumn{2}{|c|}{$\mathrm{I}_{3}$} & & \\
\hline & $1^{*}$ & $2^{*}$ & $1^{*}$ & $2^{*}$ & $1^{*}$ & $2^{*}$ & $1^{*}$ & $2^{*}$ & $1^{*}$ & $2^{*}$ \\
\hline $\mathrm{ZT}$ & 276 & 341 & 349 & 426 & 406 & 484 & 445 & 498 & 369 & 437 \\
\hline $\mathrm{RT}$ & 290 & 338 & 365 & 426 & 350 & 464 & 460 & 522 & 366 & 437 \\
\hline CT & 291 & 350 & 360 & 433 & 402 & 478 & 446 & 501 & 375 & 440 \\
\hline Mean & 286 & 343 & 358 & 428 & 386 & 475 & 450 & 507 & 370 & 438 \\
\hline
\end{tabular}

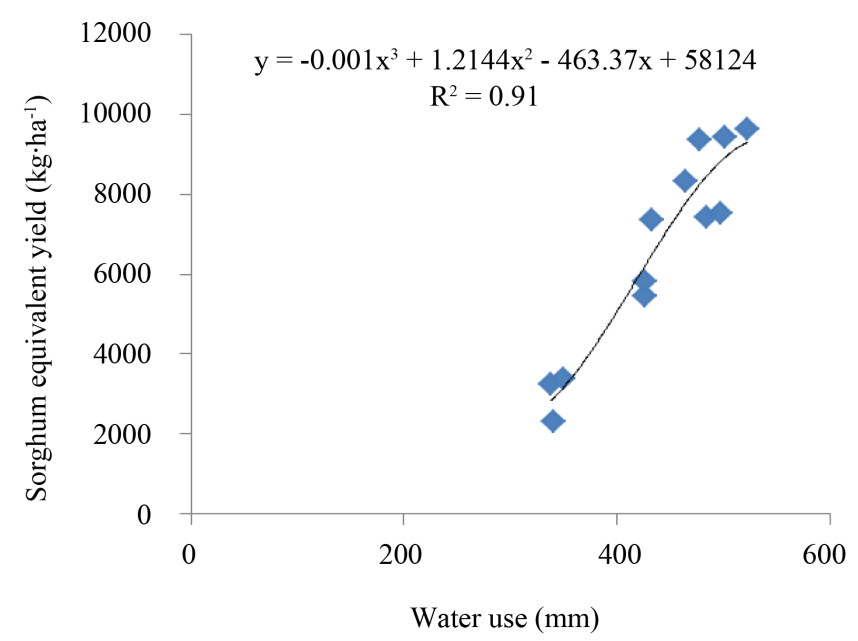

Figure 4. Sorghum equivalent grain yield of sorghum-pigeonpea intercrop as a function of water use.

$\square$ B:C (Sorghum) $\quad$ B:C (SEY)

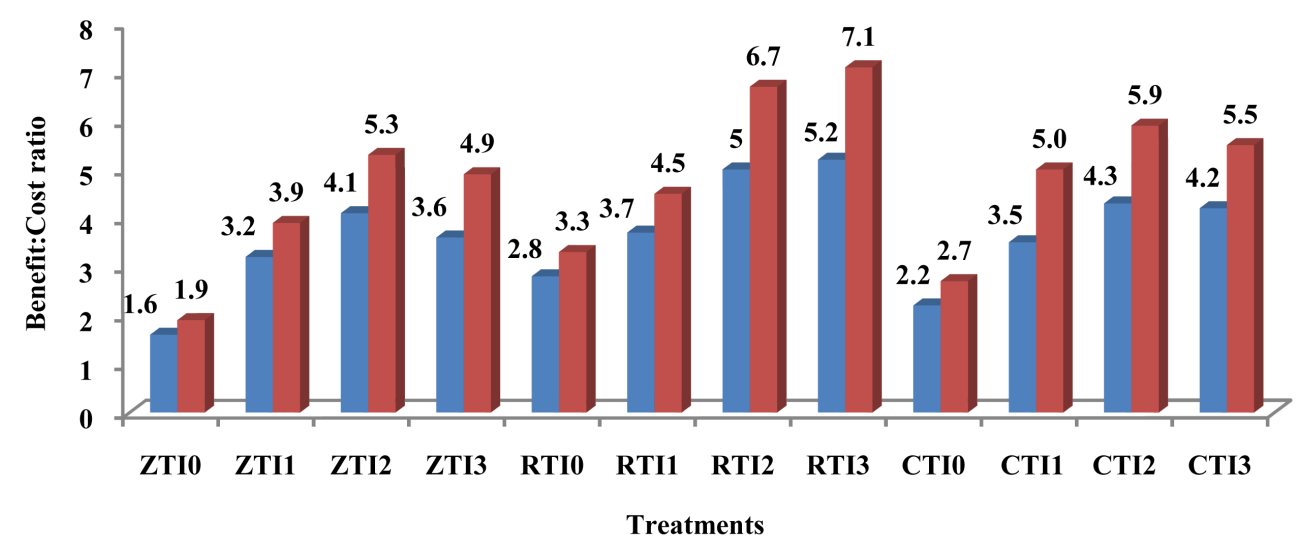

Figure 5. Benefit: Cost ratio of sorghum and sorghum equivalent yields in sorghum-pigeonpea intercrop.

\subsection{Benefit-Cost Ratio}

Benefit-cost ratio (B:C) of sorghum and sorghum equivalent yields (SEY) show that sorghum-pigeonpea intercrop was beneficial at all tillage and irrigation levels (Figure 5). Maximum benefit was 7.1 from SEY as against 5.2 from sorghum alone in RTI3 followed by that in RTI2 and CTI2. Residual soil moisture after sorghum harvesting was more important for pigeonpea than tillage. Benefit was doubled by even 50\% of full irrigation and was 4 times in RTI2 (75\% of full irrigation) compared to ZTI0. 


\section{Conclusions}

1) Pigeonpea does not compete until sorghum maturity and accelerates growth after sorghum harvesting.

2) About $80 \%$ sorghum roots in sorghum-pigeonpea intercrop are within $0.6 \mathrm{~m}$ profile whereas $>75 \%$ pigeonpea roots are below $0.60 \mathrm{~m}$ indicating weak competition.

3) Single tillage 4 days after heavy rainfall and $75 \%$ of full irrigation at $50 \%$ depletion of soil moisture from 1 $\mathrm{m}$ profile was sufficient for optimum yields of sorghum and pigeonpea.

4) Average water use efficiency increased from $12.6 \mathrm{~kg} \cdot \mathrm{ha}^{-1} \cdot \mathrm{mm}^{-1}$ for sorghum to $17.1 \mathrm{~kg} \cdot \mathrm{ha}^{-1} \cdot \mathrm{mm}^{-1}$ for sorghum + pigeonpea.

5) Benefit-cost ratio increased from 5.2 for sorghum alone to 7.1 for sorghum + pigeonpea.

6) Pigeonpea can be produced successfully on the inputs made for sorghum in sorghum-pigeonpea intercrop.

\section{Acknowledgements}

The senior author is grateful to National Board of Higher Education and Hamelmalo Agricultural College for allowing joining M.Sc. in Applied Soil Science, Department of Land Resources and Environment and financing the thesis research. Authors are also grateful to UNDP for providing funds from SGP/GEF grant for carrying out the research.

\section{References}

[1] MOLWE (Ministry of Land, Water and Environment) (2001) Eritrea’s Initial National Communication. National Report, Asmara.

[2] MOA (Ministry of Agriculture) (2005) Area and Production by Zoba from 1992-2005.

[3] Isaac, K (2008) Effect of Conservation Tillage Practices on Soil Properties, Growth and Yield of Sorghum (sorghum bicolour L.) in the semi arid region of Eritrea. M.Sc. Thesis, Hamelmalo Agricultural College, Keren.

[4] Tripathi, R.P. and Ogbazghi, W. (2010) Development and Management of a Hilly Watershed in Hamelmalo Agricultural College Farm, as a Demonstration Site for Farmers and a Study Site for Students. Final Technical Report of the Project Financed by Eastern and Southern Africa Partnership Programme (ESAAP), Department of Land Resources and Environment, Hamelmalo Agricultural College, Keren, 59 p.

[5] Tripathi, R.P., Ogbazghi, W., Amlesom, S. and Araia, W. (2014) Optimizing Tillage and Rainwater Conservation in the Soils of Hamelmalo Region of Eritrea for Arresting Soil Degradation and Achieving Sustainable High Crop Yields. Final Technical Report of the Project Financed by GEF/SGP,UNDP, Department of Land Resources and Environment, Hamelmalo Agricultural College, Keren, 112 p.

[6] Tripathi, R.P., Kafil, I. and Ogbazghi, W. (2015) Tillage and Irrigation Requirements of Sorghum (Sorghum bicolor L.) at Hamelmalo, Anseba Region of Eritrea. Open Journal of Soil Science, 5, 287-298. http://dx.doi.org/10.4236/ojss.2015.512027

[7] Oweis, T., Hachum, A. and Kijne, J. (1999) Water Harvesting and Supplemental Irrigation for Improved Water Use Efficiency in the Dry Areas. SWIM Paper 7. International Water Management Institute, Colombo. http://www.cgiar.org

[8] Bisrat, G. and Abraham, M. (2003) Introducing Small-Scale Irrigation Technology in Eritrea: Lessons and Experiences. In: Mehari, T. and Ghebru, B., Eds., Irrigation Development in Eritrea: Potentials and Constraints, Proceedings of the Workshop of the Association of Eritreans in Agricultural Sciences (AEAS) and the Sustainable Land Management Programme (SLM), Eritrea, 14-15 August 2003, 135 p.

[9] Amlesom, S. (2003) Review of Irrigation Development in Eritrea. In: Mehari, T. and Ghebru, B., Eds., Irrigation Development in Eritrea: Potentials and Constraints, Proceedings of the Workshop of the Association of Eritreans in Agricultural Sciences (AEAS) and the Sustainable Land Management Programme (SLM), Eritrea, 14-15 August 2003, $135 \mathrm{p}$.

[10] Zeneb, H. (2003) Rainfall Input to Irrigation Development in Eritrea: Potentials and Constraints. In: Mehari, T. and Ghebru, B., Eds., Irrigation Development in Eritrea: Potentials and Constraints. Proceedings of the Workshop of the Association of Eritreans in Agricultural Sciences (AEAS) and the Sustainable Land Management Programme (SLM), Eritrea, 14-15 August 2003, 135 p.

[11] Jason, K. (2010) Growth and Development of Sorghum. In: Espinoza, L. and Kelley, J., Eds., Grain Sorghum Production Handbook, University of Arkansas, Fayetteville, 123-145.

[12] Sivakumar, M.V.K. (1989) Agro Climatic Aspects of Rainfed Agriculture in the Sudano-Sahelianzone. Proceedings of the International Workshop on Soil, Crop and Water Management Systems for Rain Fed Agriculture in the Sudano- 
Sahelian Zone, ICRISAT Sahelian Center, Niamey, 7-11 January 1987, 17-38.

[13] Krishna, H.J. (1982) Using Rainfall Excess for Supplemental Irrigation of Vertisols in India. Proceedings of the Symposium on Rainwater and Dryland Agriculture, New Delhi, 3 October 1980, 76-83.

[14] Sharma, P. and Abrol, V. (2012) Tillage Effects on Soil Health and Crop Productivity: A Review. In: Sharma, P. and Abrol, V., Eds., Crop Production Technologies, InTech, Rijeka, 245-262.

http://www.intechopen.com/books/crop-production-technologies/tillage-effects-on-soil-health-and-cropproductivity-a-r eview http://dx.doi.org/10.5772/28237

[15] Majid, R. and Fereydoun, K. (2008) Effect of Different Tillage Methods on Soil Physical Properties and Crop Yield of Melon (Cucumis melo). ARPN Journal of Agricultural and Biological Science, 3, 41-46.

[16] Gajri, P.R., Majumdar, S.P. and Pradeep, K.S. (2009) Tillage. In Fundamentals of Soil Science. Indian Society of Soil Science, New Delhi, 161-175.

[17] Ignatius (2011) Effect of Tillage Practices on Soil Fertility: A Case Study of the West Mamprusi District of Northern Region. M.Sc. Thesis, Kwame Nkrumah University of Science and Technology, Kumasi.

[18] Paustian, K., Collins, H.P. and Paul, E.A. (1997) Management Controls in Soil Carbon. In: Paul, E.A., Paustian, K., Elliott, E.T. and Cole, C.V., Eds., Soil Organic Matter in Temperate Ecosystems: Long-Term Experiments North America, CRC Press, Boca Raton, 15-49.

[19] Brady, N.C. and Weil, R.R. (2002) The Nature and Properties of Soils. 13th Edition, Prentice-Hall, Inc., Upper Saddle River.

[20] Havlin, J.L., Beaton, J.D., Tisdale, S.L. and Nelson, W.L. (2005) Soil Fertility and Fertilizers. An Introduction to Nutrient Management. Pearson Education, Inc., Upper Saddle River.

[21] West, L.T., Miller, W.P., Bruce, R.R., Langdale, G.W., Laflen, J.M. and Thomas, A.W. (1992) Cropping System and Consolidation Effect on Rill Erosion in the Georgig Piedmont. Soil Science Society of America Journal, 56, 1238-1243. http://dx.doi.org/10.2136/sssaj1992.03615995005600040038x

[22] Bear, M.H., Cabrera, M.L., Hendrix, P.F. and Coleman, D.C. (1994) Aggregate Protected and Unprotected Organic Matter Pools in Conventional and No-Tillage Soil. Soil Science Society of America Journal, 58, 787-795. http://dx.doi.org/10.2136/sssaj1994.03615995005800030021x

[23] Bahri, H., Annabi, M., Chibani, R., Angar, H. and Bahri, H.S. (2010) No-Tillage Practice Effect on Soil Aggregate Stability in Northern Tunisia. INRGREF, Genie Rural Laboratory, Rue Hedikaray-Ariana.

[24] Oades, J.M. (1984) Soil Organic Matter and Structural Stability: Mechanisms and Implications for Management. Plant and Soil, 76, 319-337. http://dx.doi.org/10.1007/BF02205590

[25] Bruce, R.R. (1990) Tillage and Crop Rotation Effect on Characteristics of Sands Surface Soil. Soil Science Society of America Journal, 54, 1744-1747. http://dx.doi.org/10.2136/sssaj1990.03615995005400060039x

[26] Chenu, C., Le Bissonnais, Y. and Arrouays, D. (2000) Organic Matter Influence on Clay Wettability and Soil Aggregate Stability. Soil Science Society of America Journal, 64, 1479-1486. http://dx.doi.org/10.2136/sssaj2000.6441479x

[27] Wei, C.F., Gao, M., Che, F.C. and Deng, C. (1990) The Study on the Changes of Thermal and Moisture Conditions of Soil Aggregate under Ridge No-Tillage Rice Land. Acta Pedologica Sinica, 27, 171-177.

[28] Unger, P.W. (1984) Tillage Systems for Soil and Water Conservation. Soils Bulletin 54, FAO, Rome.

[29] Ball-Coelho, B.R., Roy, R.C. and Swanton, C.J. (1998) Tillage Alters Corn Root Distribution in Coarse-Textured Soil. Soil and Tillage Research, 45, 237-249. http://dx.doi.org/10.1016/S0167-1987(97)00086-X

[30] Derpsch, R. (2008) No-Tillage and Conservation Agriculture: A Progress Report. In: Goddard, T., Zoebisch, M., Gan, Y., Ellis, W., Watson, A. and Sombatpanit, S., Eds., No-Till Farming Systems, World Association of Soil and Water Conservation, Bangkok, 7-42.

[31] Wallis, E.S., Whiteman, P.C. and Akinola, J.O. (1975) Pigeonpea (Cajanus cajan (L.) Milli sp.) Research in Australia. International Workshop of Legume Crops, ICRISAT, Patancheru, 13-16 January 1975, 149-165.

[32] Sharma, D. and Green, J.M. (1975) Perspective of Pigeonpea and ICRISAT’S Breeding Program. Research in Australia. International Workshop of Legume Crops, ICRISAT, Patancheru, 13-16 January 1975, 19-29.

[33] Sheldrake, A.K. (1984) Chickpea and Pigeonpea. Leaf Drop in Fluencies Harvest Index Measurement. There Is a Built-In Bias in Our Estimates. Research in Australia. International Workshop of Legume Crops, ICRISAT, Patancheru.

[34] Nene, Y.L. (1987) Overview of Pulses Research at ICRISAT. ICRISAT, Patancheru.

[35] Egbe, O.M. and Idoko, J.A. (2012) Evaluation of Pigeonpea Genotypes for Intercropping with Maize and Sorghum in Southern Guinea Savanna: Economic Benefits. International Journal of Agriculture and Forestry, 2, 108-114. http://journal.sapub.org/ijaf 
http://dx.doi.org/10.5923/j.ijaf.20120201.17

[36] Gwata, E.T. and Shimelis, H. (2010) Evaluation of Pigeonpea Germplasm for Important Agronomic Traits in Southern Africa. In: Goyal, A. and Asif, M., Eds., Crop Production, InTech, Rijeka, 1-15.

[37] Pathak, S.C. and Tifton, C. (2013) Guidelines for Production of Pigeonpea (Cajanus cajan). USA. www.petcherseeds.com

[38] Egbe, O.M. (2005) Evaluation of Some Agronomic Potentials of Pigeonpea Genotypes for Intercropping with Maize and Sorghum in Southern Guinea Savanna. PhD Thesis, University of Agriculture, Makurdi. http://www.sciencepub.net/nature

[39] Peoples, M.B. and Craswell, E.T. (1992) Biological Nitrogen Fixation: Investments, Expectations, and Actual Contributions to Agriculture. Plant and Soil, 141, 13-40. http://www.sciencepub.net/nature http://dx.doi.org/10.1007/BF00011308

[40] Egbe, O.M. (2007) Assessment of Biological Nitrogen Fixing Potentials of Pigeonpea Genotypes Intercropped with Sorghum for Soil Fertility Improvement in Southern Guinea Savanna of Nigeria. Agro-Science, 6, 33-45. http://www.sciencepub.net/nature http://dx.doi.org/10.4314/as.v6i1.1554

[41] Preston, S. (2003) Intercropping Principles and Production Practices: Agronomy Systems Guide. ATTRRA, Fayetteville, 9-10.

[42] Vijayalakrhmi, K., Vittal, K.P.R. and Singh, R.P. (1982) Water Harvesting and Reuse. In: A Decade of Dry Land Agricultural Research in India 1971-80, All India Coordinated Project on Dryland Agriculture, Hyderabad, 103-139. www.knowledgebank.irri.org

[43] Tennant, D. (1975) A Test of Modified Line Intersect Method of Estimating Root Length. Journal of Ecology, 63, 995-1001. http://dx.doi.org/10.2307/2258617 